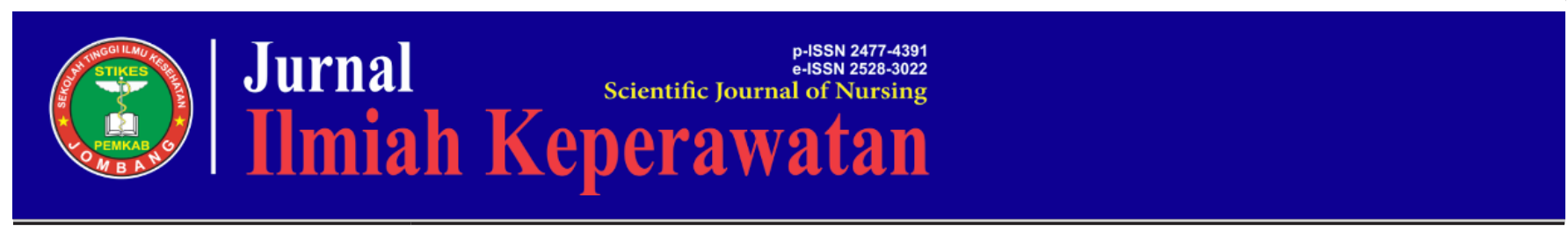

\title{
EFFECTIVENESS OF PEPPERMINT AROMATHERAPY TO MINIMIZE SHORTNESS OF BREATH IN PATIENTS WITH PULMONARY TUBERCULOSIS
}

\author{
Nunung Nurhayati ${ }^{1}$, Eva Supriatin ${ }^{2}$, Linlin Lindayani ${ }^{3}$
}

\begin{abstract}
1.STIKep PPNI Jawa Barat
2. STIKep PPNI Jawa Barat

3. STIKep PPNI Jawa Barat
\end{abstract}

\section{Riwayat artikel}

Diajukan: 07 Juli 2021

Diterima: 20 Juli 2021

Email Korespondensi: Inlnlindayani@gmail.com

\section{Kata Kunci:}

Peppermint Aromatherapy, Shortness Of Breath, Tuberculosis

\begin{abstract}
Tuberculosis is an infectious disease caused by the bacteria Mycobacterium tuberculosis with various symptoms. It spreads through droplets of people infected with TB bacilli. Patients with pulmonary TB have several different complaints that can exacerbate respiratory difficulties, including shortness of breath. Inhalation is a form of treatment by supplying steam ventilation directly to the respiratory tract. EBN is developed to assess the potency of aromatherapy peppermint to minimize shortness of breath in patients with pulmonary tuberculosis. This EBN uses literature-based approaches to analyze study findings collected from method article filter searches using Google Scholar and PubMed databases. Results revealed that the use of peppermint aromatherapy was successful against shortness of breath in patients with pulmonary tuberculosis.
\end{abstract}




\section{INTRODUCTION}

Tuberculosis (TB) is an infectious disease caused by bacteria that invade the lungs, namely Mycobacterium tuberculosis, an acid-resistant bacteria that spreads by droplets of people infected with $\mathrm{TB}$ bacilli. Pulmonary TB is an infectious disease that causes death and morbidity globally, although the prevalence rate ranges from country to country (Black \& Hawks, 2014).

According to the International Health Organisation (WHO), tuberculosis is a disease of worldwide importance. Various prevention efforts have been made to reduce the rate of tuberculosis mortality, including 1,3 million deaths in 2017 from pulmonary TB. India , China (9\%), Indonesia , the Philippines (6\%) and Pakistan (5\%) are the five countries with the largest rate of cases (World Health Organization, 2018).

Indonesia ranks third among the world's highest cases of tuberculosis (TB), although the total number of TB cases in Indonesia is 845,000 in 2019. In the meanwhile, 69 percent or around 540,000 individuals have been reported. This figure has risen from the previous 843,000, making Indonesia one of the countries that account for 60 per cent of all TB cases worldwide. On the basis of the 2019 data study, 11 people in Indonesia die every 1 hour of tuberculosis (Kemenkes RI 2019).

The prevalence of pulmonary tuberculosis in Indonesia is growing and there are high recorded cases in provinces with large populations, namely West Java, East Java and Central Java. Of the 842,000 cases of pulmonary TB in Indonesia, some 127,000 of which are West Java, only 50\% have been treated (Kemenkes RI 2019).

Tuberculosis induces different complications, according to WHO there are six symptoms of pulmonary tuberculosis, one of which is shortness of breath. Breathing shortness of breath is the inability to clean up secretions or congestion of the airway, in the field of shortness of breath with as much as 124 cases of pulmonary tuberculosis or $4.8 \%$ of a total of 2573 patients with $\mathrm{TB}$, the effect of shortness of breath if not treated is widespread disruption to the lung parenchyma, breath loss that can cause organ damage, unnecessary symptoms and even pain (Claassens et al.
2017).

Mycobacterium tuberculosis is an acid-resistant bacteria that induces the diffusion of oxygen that is interrupted by inflammation of the alveolar wall. As the lungs that are attacked spread, the cells will die and the lungs will shrink, so the patient will feel shortness of breath. Risk factors that can cause shortness of breath to escalate are affected by age, ethnicity, nutritional status and socio-economic factors. Lifestyle factors may also affect stamina (Akbar 2019)

In consideration of this phenomenon, action to minimize shortness of breath can be undertaken through the application of pharmacological and non-pharmacological treatment. Pharmacological treatment for people with pulmonary tuberculosis includes oxygen therapy for shortness of breath, nebulizers and anti-tuberculosis medications. The purpose of this pharmacological action is to cure or treat patients, avoid death, prevent recurrence or resistance to anti-tuberculosis drugs and sever the chain of transmission. And the side effects cause accelerated tolerance when administered as a single drug, inducing reduced appetite such that body weight decreases, and the body's resistance to disease decreases (Gloria et al., 2019).

Whereas complementary medication or nonpharmacological therapy may be an alternative remedy for tuberculosis patients with clinical symptoms of shortness of breath, where intervention may include changing the location of the semi-fowler, moving the lip inhalation and easy inhalation without the use of medications, but using natural aromatherapy ingredients. This intervention decreases signs of shortness of breath, relaxes breathing, relieves respiratory status, treats bacteria, and eliminates mucus hypersecretion (Anwari, Olevianingrum, and Fatmawati 2019).

One of the complementary treatments to minimize shortness of breath is quick inhalation with peppermint aromatherapy. Peppermint aromatherapy is a medicinal action that uses natural oils that are useful for enhancing physical and psychological conditions for the better. Peppermint aromatherapy treatment was selected because it comes from nature using peppermint as a raw ingredient. Peppermint contains menthol, which is also used as a raw material for cold 
medicines. Aromatherapy menthol in peppermint has an inflammatory effect, so the airways will be open. Excessive peppermint is used to cure diseases caused by bacterial attacks because it has antibacterial properties. Peppermint can relax the bronchi and make it easier to breathe, to ease coughing, you should inhale the peppermint directly (Siswantoro 2017).

Aromatherapy peppermint includes mint leaves that contain the fragrance of menthol, which is a material derived from mentha pepita or produced synthetically. This drug can be used as a fresh fragrance component in medicinal products. Aromatherapy is inhaled through the nose and transmitted through the cilia to the olfactory nerve, accompanied by exposure to the nerves in the medulla oblongata and the brain stem sponges, which then activate the limbic system to generate the hormone serotonin responsible for the stabilization and release of emotions. Isoxazole compounds are potent partial agonists that induce a rise in Ca2 (Akbar 2019).

The effect of shortness of breath before and after peppermint aromatherapy with clear inhalation techniques is based on studies conducted by (Siswantoro 2017). The Wilcoxon-rank test findings obtained p-value $0.008<0.005, \mathrm{H}$ is denied and $\mathrm{H} 1$ is approved, that indicates that there is an effect of peppermint aromatherapy to minimize shortness of breath. Meanwhile, according to research by (Anwari et al. 2019), It is clarified that the significant value of the Man Whitney test for the frequency status of patients with $\mathrm{TB}$ occurrence is 0.034 , so it can be inferred that there is a significant difference in the cough frequency and shortness of breath of the patient following the use of peppermint aromatherapy.

Centered on the above context, the group is interested in extending the findings of the research/research on breathing to the management of cases used in EvidenceBased Nursing (EBN) entitled The Effectiveness of Peppermint Aromatherapy Against Reducing Breath Shortness in Pulmonary Tuberculosis Patients.

\section{METHOD}

This research is a systematic analysis of current literature to examine subjective reactions following the use of peppermint aromatherapy for the treatment of shortness of breath in patients with pulmonary tuberculosis (pulmonary TB).

\section{Analysis approach}

The purpose of the search technique is to locate papers that have already been written. Data from this literature review have been accessed from online searches. The quest was performed via the corpus of Google scholars and the E-Journal. The keywords used were "Pulmonary TB Patients" "Aromatherapy Peppermint" and "Shortness of Breath" The quest focused on diaries using peppermint aromatherapy to minimize shortness of breath in patients with pulmonary tuberculosis. The study used in the EBN is focused on the inclusion criteria: the types of papers in English and Indonesian, the types of articles chosen are full-text articles, the research approach is Quasy Experiment or Randomized Controlled Trial and Research Trials, the year in which articles were written over the last 10 years with a number of years from 2010 to 2020 have been revised.

\section{Article screening}

Article screening was carried out by means of the initial headline and an abstract screening was carried out to identify which papers meet the desired inclusion criterion. After evaluating all the papers found to be important at the benchmark screening level. Additional publications not listed in the original literature scan were retrieved by evaluating the sources in the report. Two reviewers reviewed each abstract on the basis of the inclusion criterion, the first reviewed both the titles and the abstract in order to prevent duplication of the report. Separately, the second reviewer evaluated the sample of titles and abstracts on the basis of the same screening criterion, and the two reviewers decided on which publications meet the inclusion criteria..

\section{Data extraction}

Each data processing article carried out by means of a review of each article includes author, year, country of origin research, types of research, samples (including sample size and inclusion criteria), interview instructions, findings and study limitations.

\section{Quality evaluation of the analysis}

The content evaluation of each article is carried out using the CASP (Critical Appraisals Skills Program) 
format in Indonesia. The criterion used to determine if each analysis is of good quality and the minimum likelihood of bias is 3, i.e. if the results of the analysis are valid, what are the effects, will improve the results of the test locally. There are 11 checklist items used for yes/no/non-reported answer choices and there are notes for each checklist item.

\section{RESULTS}

Out of the search results by Google Scholar and E-Journal, 35 journals were retrieved using a combination of the keywords aromatherapy peppermint AND shortness of breath OR respiratory dyspnea AND pulmonary tuberculosis. As many as 25 journals were collected using the keyword mix of peppermint aromatherapy and TB patients. After that it is picked according to the form of paper of the requested publication, namely 8 papers. Those that enter according to the expected inclusion requirements are then re-selected so that journal papers are submitted for review. Of the 35 posts, 5 corresponded to the intended inclusion requirements.

\section{Summary of Search Results}

Chart 1. Search Flow Diagram

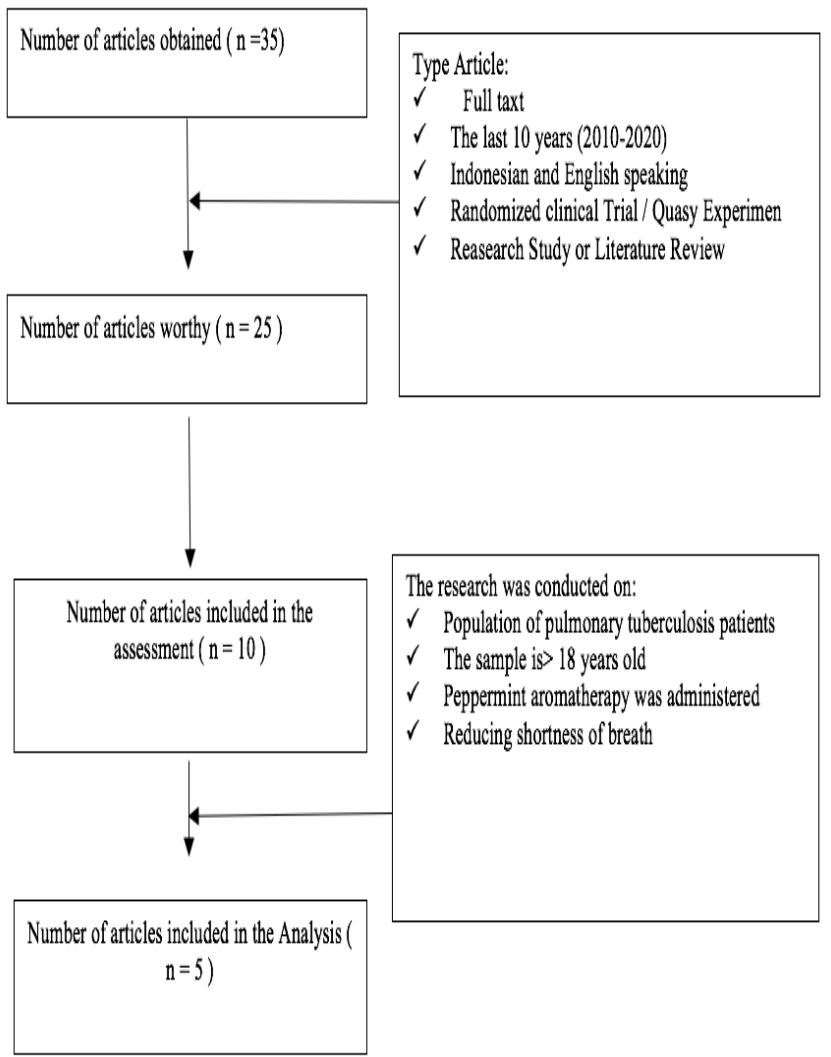




\section{Report Selected Articles}

\begin{tabular}{|c|c|c|c|c|c|c|c|c|}
\hline \multicolumn{4}{|c|}{ Author, Year } & \multicolumn{5}{|c|}{ Title } \\
\hline 1 & & \multicolumn{2}{|c|}{ (Silitonga et al. 2020) } & \multicolumn{5}{|c|}{$\begin{array}{l}\text { The Impact of Easy Inhalation Using Mint Leaves on Decreasing Breath Shortness in Lung Tuberculosis Patients in } \\
\text { Upt Puskesmas Tandang Buhit Balige Setting }\end{array}$} \\
\hline 2 & \multicolumn{3}{|c|}{ (Hutabarat, Sitepu, and Sinambela 2019) } & \multicolumn{5}{|c|}{$\begin{array}{l}\text { Impact of Quick Inhalation Using Mint Leaf Aromatherapy for Reducing Shortness of Breath in Pulmonary Tubercu- } \\
\text { losis Patients in Puskesmas }\end{array}$} \\
\hline 3 & \multicolumn{3}{|c|}{ (Aprilliawati and others 2019) } & \multicolumn{5}{|c|}{ Efforts to Improve Inadequate Airway Cleaning By Inhalation Pepperita Treatment for Tuberculosis Patients } \\
\hline 4 & \multicolumn{3}{|c|}{ (Akbar 2019) } & \multicolumn{5}{|c|}{$\begin{array}{l}\text { Intervention of Acbt Exercise Combined with Aromatherapy Mentha Pepperita L. As Supportive Treatment for Pul- } \\
\text { monary Tb Patients In Agro-Industry Sector: Literature Review }\end{array}$} \\
\hline 5 & \multicolumn{3}{|c|}{ (Siswantoro 2017) } & \multicolumn{5}{|c|}{$\begin{array}{l}\text { Impact of Mint Leaf Aromatherapy with Easy Inhalation on Reducing Breath Shortness in Pulmonary Tuberculosis } \\
\text { Patients }\end{array}$} \\
\hline \multicolumn{9}{|c|}{ Journal Analysis Results } \\
\hline No & Title & $\begin{array}{l}\text { Author, Year, } \\
\text { Country }\end{array}$ & & Partisipan & $\begin{array}{l}\text { Metode Pene- } \\
\text { litian }\end{array}$ & Intervensi & Outcome / Results & $\begin{array}{l}\text { Score } \\
\text { CASP }\end{array}$ \\
\hline 1. & $\begin{array}{l}\text { The Impact of } \\
\text { Easy Inhalation } \\
\text { Using Mint } \\
\text { Leaves on De- } \\
\text { creasing Breath } \\
\text { Shortness in Lung } \\
\text { Tuberculosis } \\
\text { Patients in Upt } \\
\text { Puskesmas Tan- } \\
\text { dang Buhit Balige } \\
\text { Setting }\end{array}$ & $\begin{array}{l}\text { (Silitonga et al. } \\
\text { 2020), Indonesia }\end{array}$ & $\begin{array}{l}\text { The population } \\
\text { average of } 30 \mathrm{pe} \\
2019 \text {. As a resu } \\
\text { ples in this stud } \\
\text { with a total of } 2\end{array}$ & $\begin{array}{l}\text { of this study was an } \\
\text { atients per month in } \\
\text { lt the number of sam- } \\
\text { ly was } 27.90 \text { patients, } \\
28 \text { respondents. }\end{array}$ & $\begin{array}{l}\text { Quantitative } \\
\text { research with } \\
\text { quasi-experi- } \\
\text { mental }\end{array}$ & $\begin{array}{l}\text { Researchers measured the degree } \\
\text { of breathlessness of patients prior } \\
\text { to the operation using the Medical } \\
\text { Research Council (MRS) shortness } \\
\text { of breath and respiratory rate. Then } \\
\text { make a quick inhalation of the mint } \\
\text { leaves for } 5 \text { minutes. The assess- } \\
\text { ment of breathing shortness and } \\
\text { respiratory rate was then carried out } \\
\text { again in conjunction with the Mint } \\
\text { Leaf Easy Inhalation SOP taken } \\
\text { from Ningrum Study }(2019) \text {. }\end{array}$ & $\begin{array}{l}\text { The results of the bivariate analysis using } \\
\text { the T-Paired T-Test produced the sig } \\
\text { value. (2-tailed) } 0.000<.005 \text {. It can be } \\
\text { inferred that there is a disparity before } \\
\text { and after simple inhalation of mint } \\
\text { leaves. The result of clear inhalation of } \\
\text { mint leaves is to minimize shortness of } \\
\text { breath in patients with pulmonary TB. }\end{array}$ & 8 \\
\hline
\end{tabular}



Inhalation Using Mint Leaf Aromatherapy for Reducing Shortness of Breath in Pulmonary Tuberculosis Patients in Puskesmas
2. Impact of Quick
The population in this sample was all pulmonary TB patients at the Pon Village Health Centre, Sei Bamban District, in 2019. The sampling methodology used in this analysis was accidental sampling where sampling was done by taking cases or respondents who were available or available, including 29 individuals.

\section{This quasi-ex-} perimental research used a one-group pre-post-

test design method, i.e. group of participants who were studied prior to intervention and then observed again after intervention.
After the experiment, the group of subjects who were studied prior to the intervention were observed again. The American Thoracic Society (ATS) shortness of breath and diffuser were the data collection devices used in this research. The data collection instrument used in this analysis was the observation checklist. The data extraction in this analysis is an observation sheet. For respondents, the technique of giving mint leaves aromatherapy with easy inhalation or using a diffuser is achieved by injecting in the instrument 2-3 drops of essential oil containing mint leaves 3 times a day within 15 minutes in a week not far from the patient, which is approximately ineffective for inhalation.

3. Efforts to Im$\begin{array}{ll}\text { Efforts to Im- } & \text { (Aprilliawati and } \\ \text { prove Inadequate } & \text { others 2019), }\end{array}$ Airway Cleaning

By Inhalation

Pepperita Treat-

ment for Tuberculosis Patients
There were people with pulmonary tuberculosis in the population, with a sample of 2 respondents.
The research approach used is descriptive

for case study (case study) research using the assessment, interview, calculation and recording tool used was a format for the mea-

surement of nursing care and SOP
Assessing respiratory symptoms that existed in 2 responders, following evidence on shortness of breath, intervention with non-pharmacological techniques i.e. peppermint aromatherapy, treatments administered once/day for 10-15 minutes, and then analyzed for 3 days.

(1)

T-Independent statistical test results obtained a $\mathrm{p}$ value of $0.000<(5-007) 0,05$ and suggested that simple inhalation with mint leaf aromatherapy (menthapiperita) had an effect on the reduction of shortness of breath in patients with pulmonary tuberculosis.

After 3 days of inhalation of peppermin aromatherapy, the respiratory rate was 3 , breathing rhythm 2 , inspiration 3 , breathing auscultation 3 with the results of Bates-Jansen Evaluation Method

before inhalation of peppermint aromatherapy score 2 to 4 . The inhalation of peppermint aromatherapy may improve the inefficiency of airway clearing in TB patients. 
4. Intervention of Acbt Exercise Combined with

Aromatherapy

Mentha Pepperita

L. As Support-

ive Treatment

for Pulmonary

Tb Patients In

Agro-Industry

Sector: Literature

Review

5. Impact of Mint Leaf Aromatherapy with Easy

Inhalation on

Reducing Breath

Shortness in Pul-

monary Tubercu-

losis Patients $\begin{array}{ll}\text { (Akbar 2019), } & \text { A literature study of } 21 \text { articles on } \\ \text { Indonesia } & \text { ACBT intervention combined with }\end{array}$ ACBT intervention combined with

aromatherapy as a therapy to reduce

shortness of breath in patients with pulmonary TB.

(Siswantoro
2017), Indonesia

The population in this study was all

who had clinical symptoms of shortnes of breath at the Sooko Health Center, Sooko District, Mojokerto Regency.

The population in this study was 17 .

After adjusting to the research criteria,

it was found that there were 16 people in the affordable population.

This research method uses

a literature re-

or a case study

Techniques" "Aromatherapy" "Tuberculosis" using the keywords "Breathing

Conduct a literature review using $\quad$ ACBT breathing exercises combined electronic databases accessed by Sci- with mint leaf aromatherapy may
eceDirect, Google scholar, PubMed, increase the stability of patients with pulmonary tuberculosis, reduce shortness of breath, stabilize breathing rates as well as relaxation, increase FEV1 and FVC values, facilitate sputum release and maintain fitness to prevent unwanted complications from occurring in patients. The community of TB Parudalangan.

\section{The research The research sample consists of 16} design used a pre-experimental approach with a pretest control group design approach. people who will be studied or the number of characteristics possessed by the population. Then out of 16 people divided into 2 , namely 8 as the treatment group and 8 as the control group. The sampling technique for this study was performed by simple random sampling.
The results of the Wilcoxon test obtained p-value data of $0.008<0.05$

which means that there is an effect of aromatherapy with simple inhalation of the results of the Mann Whitney U test show a p-value of $0.006<0.05$, which means that there is a difference between the scale value of the control group breathability without $\mathrm{m}$ being given. mint leaves on shortness of breath and 


\section{Methodological Assessment Results}

Based on the results of the journal, it can be concluded that there is a difference in time of intervention or action in the treatment of peppermint aromatherapy to reduce shortness of breath in patients with pulmonary tuberculosis. The results of research conducted by (Silitonga et al. 2020)namely Mycobacterium tuberculosis, an acid-resistant bacterium, which spreads through droplets of people infected with TB bacilli. Patients with pulmonary TB have many diverse complaints which can cause breathing problems, namely shortness of breath which can cause ineffective airway clearance.Purpose : To determine the effect of simple inhalation using mint (menthe piperitaon 28 respondents using the Medical Research Council (MRS) shortness of breath and breathing frequency, followed by inhalation of aromatherapy for 5 minutes, then continued to measure shortness of breath and the results had an effect on reducing shortness of breath in tuberculosis patients. Whereas in a study conducted by (Aprilliawati and others 2019), peppermint aromatherapy inhalation was administered once daily for 3 days as a result of an increase in the ineffectiveness of airway cleaning in patients with pulmonary tuberculosis. Research conducted by (Hutabarat et al. 2019) intervention was carried out on 29 respondents using an American Thoracic Society (ATS) measuring instrument and a diffuser where the intervention was carried out by inserting 2-3 drops of essential oil containing mint leaves 3 times/day. for 1 week, the result is the aromatherapy effect on reducing shortness of breath in tuberculosis patients.

\section{DISCUSSION}

Research conducted by (Silitonga et al. 2020)namely Mycobacterium tuberculosis, an acid-resistant bacterium, which spreads through droplets of people infected with TB bacilli. Patients with pulmonary TB have many diverse complaints which can cause breathing problems, namely shortness of breath which can cause ineffective airway clearance.Purpose : To determine the effect of simple inhalation using mint (menthe piperita is a type of quantitative quasiexperimental research with an average output of 30 patients per month in 2019. As a result the number of samples in this study was 27.90 patients, for a total of 28 respondents. When the researchers measured the degree of breathlessness of the patient prior to the procedure using the Medical Research Council (MRS) shortness of breath and respiratory rate. Then make a quick inhalation of the mint leaves for 5 minutes. Then the measurement of breathing shortness and respiratory rate was carried out again by the Mint Leaf Simple Inhalation SOP taken from Ningrum Research (2019). The results of the bivariate analysis using the T-Paired T-Test produced the sig value. (2-tailed) $0.000<.005$. It can be inferred that there is a disparity before and after simple inhalation of mint leaves. The result of clear inhalation of mint leaves is to minimize shortness of breath in patients with pulmonary TB.

The same is true of the research conducted by (Hutabarat et al. 2019) with quasi-experimental research with a one-group pre-post-testing approach i.e. a group of subjects that are observed before intervention and then observed again after intervention. The population in this sample was all pulmonary TB patients at the Pon Village Health Centre, Sei Bamban District, in 2019. The sampling technique used in this study was accidental sampling where sampling was performed by taking cases or respondents who were present or available, i.e. as many as 29 people. After the intervention, the group of subjects that were observed before the intervention were observed again. The American Thoracic Society (ATS) shortness of breath and diffuser were the data collection devices used in this research. The criteria for inclusion in this study were patients with pulmonary tuberculosis who were willing to respond, while the exclusion criteria were not met. Results of the T-. Independent statistical test obtained data of p-value $0.000<(\alpha) 0.05$, it was concluded that simple inhalation using mint leaf aromatherapy (Mentha Piperita) had an effect on the reduction of shortness of breath in patients with pulmonary tuberculosis.

Supported by research conducted by (Siswantoro 2017), with a total population of 17 in this study. After adjusting to the research criteria, it was found that there were 16 people in the affordable population. The research sample consists of 16 people to be studied or the number of characteristics possessed by the population. Then out of 16 people divided into 2 , namely 8 as the treatment group and 8 as the control group. The results of the Wilcoxon test obtained p-value data of $0.008<0.05$, which means that there is an effect of aromatherapy with simple inhalation of 
mint leaves on reduced shortness of breath, and the results of the Mann Whitney $U$ test show a p-value of $0.006<0.05$, which means that there is a difference between the scale value of the control group shortness of breath without being givrated.

Thus the intervention of mint leaf aromatherapy in the three studies has had an effect on reducing shortness of breath in patients with pulmonary $\mathrm{TB}$, which can be used when the patient experiences shortness of breath at home. The results of the literature review conducted by (Aprilliawati and others 2019) and (Akbar 2019) on the provision of peppermint aromatherapy to reduce shortness of breath in patients with pulmonary $\mathrm{TB}$ are also supported. Where inhalation of peppermint aromatherapy may increase the ineffectiveness of airway clearance in TB patients to reduce shortness of breath. Research conducted by (Akbar 2019) has shown that ACBT intervention combined with Mentha L. Pepperita Aromatherapy (Mint Leaf) as a therapy to reduce shortness of breath in patients with pulmonary $\mathrm{TB}$ can reduce shortness of breath, stabilize breathing rate, relaxation, increase FEV1 value and FVC facilitate sputum discharge and maintain fitness so as to prevent the occurrence of unwanted complications.

The similarity of the five journals obtained is that giving mint (peppermint) aromatherapy affects the reduction of shortness of breath in patients with pulmonary TB. In addition, the research journal (Hutabarat et al. 2019) has the highest CASP score of 9, which shows that this intervention is effective for patients with pulmonary tuberculosis who experience shortness of breath.

\section{CONCLUSION}

Based on the journal described in the previous chapter, it was found that the outcome of this study was the intervention of peppermint aromatherapy to reduce shortness of breath in patients with pulmonary TB. This treatment is effective in reducing shortness of breath in patients with pulmonary tuberculosis.

\section{ACKNOWLEDGEMENT}

The authors would like to thank their colleague for their contribution and their support to research. They are also grateful to all the reviewers who gave their valuable input to the manuscript and helped to complete the paper.

\section{CONFLICT OF INTEREST}

There is no conflict of interest to be declared by the author.

\section{REFERENCE}

Akbar, Fikri Haikal. 2019. "The Intervention Of Acbt Exercice Combined With Aromatherapy Mentha Piperita L. As A Complementary Therapy To Patient With Pulmonary Tb." (1):368-76.

Anwari, Farida, Melawati Olevianingrum, And Umi Fatmawati. 2019. "Efektifitas Kombinasi Mint ( Papermint Oil ) Dan Cairan.” 3(1):40-44.

Aprilliawati, Dewi, And Others. 2019. "Upaya Peningkatan Ketidakefektifan Bersihan Jalan Nafas Melalui Inhalasi Aromaterapi Peppermint Pada Penderita Tuberculosis." Diii Keperawatan.

Claassens, M. M., C. Van Schalkwyk, S. Floyd, H. Ayles, And N. Beyers. 2017. "Symptom Screening Rules To Identify Active Pulmonary Tuberculosis: Findings From The Zambian South African Tuberculosis And Hiv/Aids Reduction (Zamstar) Trial Prevalence Surveys.” Plos One 12(3):1-12. Doi: 10.1371/Journal.pone.0172881.

Hutabarat, Vitrilina, Stefani Anastasia Sitepu, And Megawati Sinambela. 2019. "Pengaruh Inhalasi Sederhana Menggunakan Aromaterapi Daun Mint (Mentha Piperita) Terhadap Penurunan Sesak Nafas Pada Pasien Tubercolosis Paru Di Puskesmas." Jurnal Penelitian Kebidanan \& Kespro 2(1):11-16. Doi: 10.36656/Jpk2r.v2i1.173.

Kemenkes Ri. 2019. "Infodatin Tuberkulosis." Kementerian Kesehatan Ri 1-8.

Silitonga, Haris, Corry Betti, Theresa Sihombing, And Irma Simangunsong. 2020. "Pengaruh Inhalasi Sederhana Menggunakan Daun Mint (Menthe Piperita) Terhadap Penurunan Sesak Napas Pada Penderita Tb Paru Di Lingkungan Upt Puskesmas Tandang Buhit Balige." Malahayati Nursing Journal 2(3):632-40. Doi: 10.33024/ Manuju.v2i3.2905.

Siswantoro, Edy. 2017. "Pengaruh Aroma Terapi Daun Mint Dengan Inhalasi Sederhana Terhadap Penurunan Sesak Nafas Pada Pasien Tuberculosis Paru." Jurnal Keperawatan Dan Kebidanan 7(1). 